\title{
Beyond Reforms: The Politics of Higher Education Transformation in Africa
}

\author{
Tade Akin Aina
}

Editors' note: This article was presented as the 2009 Bashorun M. K. O. Abiola Lecture at the fifty-second Annual Meeting of the African Studies Association in New Orleans in 2009.

\begin{abstract}
In spite of over a half century of interventions and waves of "reforms," higher education in Africa today consists of institutions, systems, and practices that lack distinct values and goals, or a mission and vision connecting them to the major challenges of their local and global contexts. What is needed in African higher education is true transformation, which will involve practical and epistemological ruptures with previous ways of doing things and a reconstruction of structures, relations, cultures, and institutions. Of particular importance are initiatives that will ensure gender equity, changes in the organization and process of knowledge production, and a reenvisioning of universities' funding sources and mechanisms.
\end{abstract}

\section{Introduction}

I would like to begin by expressing my sincere appreciation to the Board of the African Studies Association for giving me this opportunity to deliver the Bashorun M. K. O. Abiola lecture for the association's 2009 meeting. I had

African Studies Review, Volume 53, Number 1 (April 2010), pp. 21-40

Tade Akin Aina is currently the program director for higher education and libraries in Africa at the Carnegie Corporation in New York City. He has been the Ford Foundation's regional representative for eastern Africa, the deputy executive secretary of CODESRIA, and a professor of sociology at the University of Lagos. He is author of numerous journal articles and has written, co-written, and edited ten monographs and books. These include Globalization and Social Policy in Africa (coedited with Chachage S. L. Chachage, CODESRIA, 2004) and Beyond Benign Neglect: Early Childhood Care, Development and Nutrition in Lagos, Nigeria (co-written with Ibinabo Agiobu-Kemmer et al., Malthouse Press, 2008). E-mail: taa@carnegie.org 
the opportunity to work with Bashorun Abiola in the early 1990s as a member of the editorial board of the magazine The African Science Monitor. This was a periodical founded by Bashorun Abiola as part of his vision and recognition of the need for a platform to challenge not only the asymmetrical power relations that constitute dominant discourses and practices in the sciences, but also to encourage and elevate Africa's self-conception of her role in the sciences and their place in the lives and cultures of her peoples.

Given Nigeria's complex political history and Bashorun Abiola's varying role in it, I need to add here that whatever the personal, political, or ideological shortcomings of Bashorun M. K. O. Abiola may have been, he was an exceptional person in many ways. I still carry with me memories of those days of our editorial board meetings, which often were chaired by Muyiwa Awe, the former professor of physics at the University of Ibadan. At these meetings we saw a different side of Bashorun Abiola, one that was not often on public display. We heard of his passion for Africa, his often imaginative and even subversive nationalist political ideas on the global politics of knowledge, his unending commitment to keeping alive the question of reparations for Africans and peoples of African descent, and his unrelenting belief and confidence in the notion of an African renaissance, long before it became the vacuous contemporary political slogan devoid of content or traction.

The title of this lecture is "Beyond Reforms: The Politics of Higher Education Transformation in Africa." This is a topic that I believe fits the panAfrican vision of Abiola and his understanding of the role of knowledge as a means of individual and collective emancipation and advancement. It is equally relevant to the theme of the fifty-second Annual Meeting of the African Studies Association, "Africa at the Crossroads."

I must confess, however, that when I learned of the theme of the meeting, my first reaction was a slight sense of discomfort. I felt: No, not again! When is Africa ever going to be portrayed as traveling on its own chosen and productive paths? I had this image of Africa's development as nothing but a voyage of endless encounters with dangerous, pothole-strewn crossroads that baffle, bewilder, and wear out not only the pilots and cartographers of her journeys, but also her total populace of passengers cramped, as it were, in a decrepit but resilient matatu van. ${ }^{1}$ But I quickly took comfort in the fact that given the state of the world we are all in today, all humanity must be at one crossroad or another.

Indeed, the ironic and subliminal signification of such a theme is perhaps the recognition that Africa's stories of the development process are narratives of blocked transitions, routes not taken, itineraries hijacked, highways populated by robbers and bandits, and journeys led by shifty and unreliable scouts and guides. For people who travel often into unknown territories, these are commonplace experiences of journeys, both real and mythical. The hope is always that at the end of the journey one gets to the Promised Land in one piece. 
It is my submission that the stories of higher education development in Africa demonstrate many similarities in terms of content, maps, and routes with those of the larger development process. ${ }^{2}$ I therefore see this lecture as equally an opportunity for confronting some of the larger issues of most of the continent's development experience and its politics of knowledge. The questions posed for us, then, are the following: How do we understand the changes that have taken place and are taking place in the higher education terrain in Africa over the past three decades? What and who are the primary determinants and drivers of change? In what possible directions might the changes go? What social and political forces are at play? What are the obstacles to and facilitators of the different possible directions? These are questions often raised in one form or another by all those who have invested materially and intellectually in African higher education in various capacities.

And they are raised because, in spite of over a half century of interventions and waves of "reforms" (we can count at least three waves related to specific historical periods), the terrain of African higher education continues to resemble a thick forest of institutions, systems, and practices lacking clear and distinct tracks, values, and goals, or a mission and vision that connect the institutions and systems sufficiently to the major challenges of their contexts (whether global or local).

Yet the university in Africa and higher education in general remain a significant part of the overall social, economic, and cultural constitution of societies and nations. ${ }^{3}$ Higher education contributes to the formation and deployment of human capital, the cultural and social construction of values and meaning, and the capacity for individual and collective emancipation from ignorance and domination. Higher education further contributes to how the energies and products of science, technology, and the improvement of material conditions are mobilized for the well-being of individuals and groups. It provides a people with the tools and capacities for their collective and individual self-definition and empowerment, and for interpretating their relationships to themselves, to others, and to nature and their material and other environments. It provides the platform for the advanced study, dissemination, and utilization of knowledge and its products for the benefit of society and its constituents. In today's modern world, where nations and peoples seek to assert collective self-confidence and competitive advantage in all spheres, the absence of internal capacities within specific nations and regions to think responsibly and act for themselves often determines the extent of such a people's collective well-being, both material and otherwise.

For most nations of Africa in particular, given the histories of slavery, colonization, apartheid, and inequitable economic development-often interpreted by some as expressions of collective racial and/or cultural inferiority-genuine intellectual self-determination (not to be confused with intellectual isolation or "intellectual autarky") is a political, economic, and 
cultural imperative. In my view, intellectual self-determination refers to relatively autonomous and self-conscious capacities to meaningfully assess one's situation, take positions determined by one's interests and their relevance in particular situations, and to be sufficiently confident about the decisions so as to mobilize and deploy the necessary resources to achieve desired outcomes. Years of colonization, inept and corrupt postcolonial leadership, and different types of collective servitude-and more recently, economic adjustment programs that were neither internally debated nor owned by the citizens-have contributed to undermining and eroding such capacities. The systematic demeaning and subversion of higher education on the continent over the past three decades by different social actors, whether intentional or not, is one example. We have seen this demeaning of higher education in the public proclamations of some multilateral institutions stating or implying that Africa does not need universities to develop-that what it needs is to concentrate on basic education because there is a higher return on investment in basic education than in higher education. Yet higher education remains a significant element of the education pipeline.

Given Africa's current situation in terms of the indicators of human development, and its disadvantaged place in this era of globalization, what are usually referred to as reforms and reform processes-at least as they are ordinarily conceived and often applied-can neither redress nor significantly change the current directions and condition of her higher education systems. So-called reforms have actually contributed to some of the unfortunate paths taken. What is needed is for Africa to go beyond reforms-seen as managerial or technocratic tinkering and modification of formal policies, practices, and structures-and instead carry out a more fundamental and inclusive reengagement with vision, mission, structures, and values, reclaiming the political will and organization to mobilize and accomplish the necessary changes and reconfigurations. ${ }^{4}$ The time has come for leaders and stakeholders in African nations to collectively and autonomously own their universities and the higher education sector, and to make them work in their national interests and for the benefit of their countries and their peoples in inclusive and democratic ways. No outsider can do this for African countries; no donors can do this for them either. African governments, businesses, and interest groups must determine whether they genuinely need universities and higher education institutions that express excellence and equity, and they must mobilize the necessary resources needed for such a transformation.

It is my belief that transformation is possible. It is real and achievable. But it requires that we engage in an analysis of how enduring change happens. That is, in an understanding of the politics of the change process.

This, unfortunately, is not well developed in the study or thinking about higher education in Africa. The dominant perspective so far in the literature-the reform perspective-is constructed in such a way that it does not address the politics of change. Neither does it challenge cultures of depen- 
dency and mediocrity in all their ramifications. We see this reticence in the ways that issues of governance, excellence, financial sustainability, forms and contents of institutions, programs, curricular ideas, and enduring innovation are addressed. Of course, given the fact that reform perspectives have been led and driven mainly by non-Africans and are insufficiently locally owned, norms of political correctness and less-than-adequate commitment to Africa limit frank analyses and robust contestation.

But let us begin with understanding the notions and contexts of reform in African higher education.

\section{The "Reform Framework" and Universities in Africa}

When we look at the field of, and literature on, public higher education in Africa over the last two or three decades, we find that the dominant theme has been crisis and reform. We find this not only in the variety of studies and analyses, but also in the unwritten emergent practices and language with which the field is engaged by scholars and researchers, managers and administrators, donors and politicians, students and workers, and even parents and employers. These different groups either advocate or resist reform, lament the crises that produced the need for reform, or bemoan the attendant issues and challenges created by the endless cycles of reform themselves.

As it is most often written about in the literature, the notion of reform-or a "reform framework"-usually indicates "change." Technically, it is a notion that refers to planned change in the operations of a system or subsystem, or a set of processes in an institution or sector. ${ }^{5}$ But it is also a notion that is imbricated with theories and politics of change, and these often are limited in terms of how the status quo is challenged or power relations are reordered. Inspired by a "neomodernization perspective," the notion of reform is often oriented more toward bureaucratic change than social movement-inspired progress, and it is often conceived of as a topdown, hierarchical process and led by managers and technical specialists supported and often led by external aid agencies. Thus, like the modernization theories of development studies of the 1960s and 1970s, current reform perspectives carry their own baggage of ethnocentricity and teleology in terms of how they privilege specific institutional and knowledge forms, traditions and norms, and epistemologies. ${ }^{6}$

In many cases in Africa, the experience of recent reforms in higher education is linked with the economic and political crises of the 1970s and 1980 s that preceded them. However, we must be careful about how we refer to the African experience. It is true that many countries suffered from the economic crises of the 1970 s and 1980 s, but these were experienced in different ways by different countries, depending on the nature of their economies and other factors such as how they were integrated into regional and global economies. For instance, the Francophone countries of West Africa were affected very differently from the ways in which Ghana, Sierra 
Leone, Liberia, and Nigeria were affected. The Maghreb experiences were also different, and Egypt for a long time demonstrated an exceptionalism that was the result of her relationship with the West and the extent of aid from the U.S. South Africa was of course for many years before 1994 locked in to its closed apartheid system, which produced a vast racist, unequal, and unjust society and higher education sector. Political unrest, wars, and cycles of ecological disasters also further exacerbated the economic crisis.

But the crisis did catch up with most African countries, and by the late 1980 s to early 1990s it had become a proclaimed element of the "African condition," to use the notion popularized by Ali Mazrui. And, in responding to the crises with specific reform packages, the tendency was to generate more crises or exacerbate already existing ones in many countries and institutions.

What, then, is the dominant "reform framework"? It is a battery of discourses, practices, and policies built on a set of predominantly neoliberal and market-driven assumptions, diagnoses, and prescriptions for a specific set of situations in many African universities and the higher education sector. In the 1990 s it was a specific way of seeing, thinking, and speaking about African universities in particular and African economies in general within specific contexts of crisis and degradation. But beyond these specific contexts it has unfortunately become a generalized and conventional way of seeing and thinking about African universities. Given its perspective of "emergency," it is focused on immediate, short-term relief and rehabilitation that does not address long-term goals and vision. Starting out as a framework that emerged from context-specific and time-bound experiences, it has become standard and universal fare for engaging African higher education and thinking about its future. Originally a set of shortterm, emergency prescriptions and approaches emphasizing rehabilitation and revitalization, it has become an ossified culture and mode of thinking about African universities with its own functionaries, ideologues, and practitioners. As a result, it has tremendous potential to stifle innovation, vision, and long-term thinking, and it precludes any real and enduring transformation of African universities and the higher education sector.

\section{The Crisis and Its Origins}

Let us examine the genesis of this crisis. Our efforts have been helped by the large amount of literature produced by both African and non-African scholars on the subject. ${ }^{7}$

A huge section of the literature (e.g., Aina 1994; Mama 2003; Ajayi, Goma, \& Johnson 1996; Zeleza 2004) tells us that the origins of the most recent crises in higher education in Africa can be located in the development crisis faced by many countries on the continent from the $1970 \mathrm{~s}$ on. This was the time when a combination of adverse conditions such as the crash in commodity markets and the rapid rise of oil prices began to mani- 
fest themselves. The resulting economic downturn produced the first serious "fiscal crisis of the state" in postcolonial Africa. Many governments found themselves with serious balance-of-payment deficits, leading them to resort to bilateral, multilateral, and private international (predominantly Western) financiers for short- and long-term credit. As the indebtedness of the states grew, resolving the problem became an increasingly coordinated affair between a group of poor, heavily indebted countries and their creditors made up of national governments, international organizations, and private enterprises. The dominant institutional actors in these negotiations and efforts at adjustment and recovery were the Bretton Woods Institutions (BWIs), namely the World Bank and the International Monetary Fund.

These were difficult times for many African countries all around, as the economic crises were accompanied by growing political crises that manifested themselves first in what has been characterized as the disintegration of the nationalist coalitions and projects and the rise of authoritarian politics in Africa (Anyang' Nyong'O 1989). Nationalist politics deteriorated into authoritarian politics, and Africa's decolonization hopes and dreams became its postcolonial nightmare.

Authoritarian politics had different facets. They included multiple military coups, the prevalence of military regimes (some of them led by break-dancing juvenile delinquents), one-party states, and the occasional demented personal ruler, all of which provided much disparaging material for the Western media. Perhaps one of the most interesting aspects of the African experience with authoritarian politics was that its highpoints coincided with the highpoints of the global Cold War politics that pitted Western powers against the now defunct Soviet Union. The geopolitical struggles between the two powers had far-reaching implications for the expression, organization, and mobilization of democratic rights in Africa, as most groups that opposed authoritarian rule on either side of the Cold War divide invoked the wrath of both their rulers and their external backers, who provided both the resources and technologies of repression.

Irrespective of the state of their mental health, the authoritarian rulers of Africa in the 1970s and 1980s were cunning enough to engage in the Cold War politics of playing the big powers against each other while extending their grip of oppression and exploitation on their own populations. Indeed, what has been called "Africa's lost decades," the decades of crises and authoritarian rule, owed their existence and perpetuation to an unholy alliance of internal and external factors and agents.

Authoritarian politics significantly affected higher education even in countries with enlightened political leadership such as Tanzania. As Mamdani (2008:6) has pointed out in regard to the "developmentalist university" exemplified by the University of Dar Es Salaam, "the more nationalism turned into a state project, the more there were pressures on the developmentalist university to implement a state-determined agenda. The more this happened, the more critical thought was taken as subversive of the 
national project." And to make matters worse, the universities were breeding grounds for a counterelite. On this point, Mamdani (2008:5) notes that "the University was of course an incubator of both critical thought and of [a] counter-elite whose critique sometimes veiled ambition. The more professors sounded like ministers-in-waiting and sometimes even Presidents-inwaiting, the more their critique began to sound self-serving. In a single party context, the university began to take on the veneer of the opposition party, giving rise to confrontations that often led to strikes and shutdowns."

Thus, even before the fiscal crisis began to bite and the international financial institutions imposed the adjustment and stabilization policies, the increasingly authoritarian postcolonial political leaders of Africa in the 1970s and 1980s did not take kindly to their universities' fulfilling their role of providing independent critical thinking. As the postcolonial political elites struggled with the multiple tasks of nation-building and development, along with their own wide range of flawed motivations and strategies, the universities were increasingly seen as sites of dissent and opposition.

In fact, this conflict in certain cases went as far back as the immediate postcolonial era. Ajayi, Goma, and Johnson (1996:86-88) document the struggles between Kwame Nkrumah and the ruling nationalist party at independence, the Convention Peoples Party (CPP), and the predominantly expatriate authorities of what was then University College, Legon, over its affiliation with the University of London and other related autonomy issues. As these authors summarize the conflicts of this era,

To some extent, the politicians regarded the universities, dominated as they were by expatriate staff, as part of the apparatus of imperialism, comparable to multinational corporations, which had to be decolonized. To that extent, the politicians had the support of many African academics in their struggle to control and direct the universities. In what has been called "a destructive conflict," it was the expatriate staff defending their established privileges who called for the defence of university autonomy and maintenance of universal standards while the African staff, many of whom felt alienated and discriminated against, tended to seek the intervention of politicians to give the universities a national character and ensure rapid Africanization. (1996:95)

The politics of colonial transition, coupled with the critical posture and militancy of African university staff and students, created traditions of suspicion and barely veiled hostility between African politicians and rulers and their universities which have lasted till today. Well before the fiscal crisis, therefore, the universities were already experiencing crises related to their very constitution, namely crises of autonomy, academic freedom, the redefinition of their role and place in the postcolonial context, and their struggles for legitimacy and acceptance within wider international knowledge communities. 


\section{Reforms, Process, and Politics}

However, the most significant challenge to the health of African universities came from the neoliberal policy package designed mainly by the World Bank and the International Monetary Fund in response to the economic and political crises faced by African countries in the 1970s and 1980s. The main priority was addressing economic woes through the massive liberalization and deregulation initiatives known as structural adjustment and economic stabilization programs. ${ }^{8}$ For the universities, as Luhanga (2009), Mamdani, (2007), Assie-Lumumba (2006), and Pereira (2007) have all carefully documented, they involved the introduction of privatization, cost-sharing, financial decentralization, rationalization, retrenchment of staff, and dilution of academic programs, leading to what Mamdani has described as "vocationalization" in the universities.

In the political sphere, the introduction of political liberalization and multiparty politics-made up mainly of a return to competitive electoral politics, attempts at restoration of the formal rule of law, and rebuilding adherence to human rights and democratic institutions as defined from dominant Western perspectives-constituted the other plank of the neoliberal reform package. At first, it was concerned only with multiparty electoral politics, but later on it began to address governance issues of transparency and accountability, particularly the issue of government corruption. But again, the political elements failed to tackle important issues of transitional justice (such as truth and reconciliation, economic crimes, and crimes against humanity), to engage and tackle cultures of impunity, or to set agendas for the reconstruction of states, public institutions, and in some cases significantly traumatized and disoriented societies and social groups.

All of these macrostructural problems affected the public university sector in many African countries in different ways, given their respective contexts. Some universities and higher education systems experienced more negative effects than others. It would not be wrong to say, though, that for most public universities in Africa, the reform process was not always a benign or positive experience. At the institutional level, the combination of the larger development crisis and the political pressures on universities created the conditions that have been well documented. Some of these elements included (1) declining revenue for university teaching and research; (2) increasing and uncontrolled enrollments, leading to crowded lecture halls and residences, and pressure on staff and facilities; (3) a weak and decaying infrastructure, including inadequate buildings, equipment, laboratories, and connectivity; (4) inadequate staffing as a result of the "brain drain," high enrollments, and underqualified staff; (5) inadequate and often insufficient research and in most cases research delinked from teaching; (6) outdated and often irrelevant pedagogical modes and curricula; (7) significantly eroded intellectual communities that also were insufficiently connected to one another on the continent and also to the outside world, 
particularly the global South; (8) the prevalence of inherited outdated, and inequitable colonial governance, and administrative and academic systems with minimal accountability, transparency, and inclusiveness; (9) frequent demonstrations and crises (leading to incessant closures affecting the academic calendar) as universities and tertiary institutions become the last outposts of resistance to political authoritarianism; and (10) the expansion of internal negative cultural practices that encouraged the growth of violent secret societies on campus, sexism, academic and bureaucratic corruption, and the interference of political parties and ethnic and other associations in university life.

No honest observer can deny that most public universities (the dominant form) in many parts of Africa were in a terrible state, perhaps in need of an emergency response and drastic solutions. Given the situation depicted above, the reform process had some positive aspects by changing some archaic assumptions, practices, and structures-specifically, those that had emerged from the universities' earlier histories as colonial or immediate postcolonial nationalist institutions that had inherited the elitist privileges and exclusionist tendencies of the colonial order without significantly changing them. And this point is at the heart of the matter with regard to the nature and function of the universities in Africa.

The language and practice of reform have always been framed by a managerialist and incremental perspective concerned with operations, processes, and functions. The reform process scarcely attempts to confront values or the power relations inherent in organizations or the fundamental assumptions that define their existence. The reform process addresses efficiency and effectiveness variables and does not question the status quo. For instance, it does not question the racism or hierarchy of the colonial order that surfaced as soon as colonialists began to be replaced with nationals; it does not question sexism or offer affirmative action for women; it does not question the international division of academic and intellectual labor, recommending new laboratories, libraries, and capacity-building for academics without engaging the structures of global academic mobility or the politics of international publishing, the definition of standards, and academic ratings.

In the situation of many African universities, the recent reform process was top-down in terms of the boundaries of engagement and it did not provide adequate space or opportunity for discussions, debates, and reflection. It was as if an alliance had been created between Abraham Maslow and Niccolo Machiavelli, with individuals located on a particular point in Maslow's hierarchy of needs and Machiavellian "fraud and force" brought in to ensure compliance. It is no wonder that there was so much "malicious compliance" around structural adjustment programs in Africa, which brought the principle of Maslow's hierarchy of needs to African universities: that is, deal first with your lower order needs before approaching the higher order needs of the nature of knowledge production, the validation and relevance 
of content, and the organization of its production. Yet for Maslow, intellectual activity is a higher order need!

If we were to think about the development of the modern university in Africa in terms of discrete periods, we can broadly identify the colonial, the nationalist, and the crisis and reform-or what can now be called the neoliberal-periods. ${ }^{9}$ Each period was characterized by a specific broad, dominant mission and set of mandates for the universities. And each period involved a wave or more of reforms that supposedly addressed the inadequacies and defects of the previous era.

The colonial era university embodied both the colonial mission of producing personnel to carry out the functions of colonial society and, depending on who the colonial master was, fulfilling a set of accompanying cultural and political goals. Paradoxically, the colonial era provided the impetus for the nationalist struggles for formal decolonization and the ascension of native African male politicians to power and positions of control in most of the inherited colonial institutions.

The nationalist era saw the creation of new universities or the restructuring of the colonial universities as instruments for attaining national goals of development and nation-building. This era saw the rise of the developmentalist universities. It was also the era of what has been called the "state-controlled model." According to Assie-Lumumba (2006:68), "the state-controlled model was characterized as nearly the sole agent of subsidy of higher education: full scholarships including travel expenses, local transportation, health care, boarding, lodging and monthly stipends and living expenses to all students who in theory were 'qualified' or those who had family or personal connections to attend universities." The fiscal crisis of the state in Africa made this model unsustainable. It crumbled, but not without prolonged resistance by individuals and groups that were its beneficiaries and were ideologically and emotionally invested in it. However, varied vestiges of this model survived the reform process and remain the subjects of negotiation and agitation in the public university system in some countries.

The introduction of the structural adjustment and economic stabilization programs in the late 1970 s and 1980 s gave rise to the neoliberal era and the more or less market-driven university mission, along with the massive deregulation of the higher education sector. This era has been called "the lost decades" by many African scholars, and in the case of the higher education sector, no less a scholar than Ken Prewitt (2004:54) has called it the phase of "damage control." Mamdani (2007, 2008), Luhanga (2009), and Pereira (2007) have documented the extensive politics that dominated this era.

The politics of neoliberal reform were played out on several levelsinternational, national, local, and within institutions and their subunits and departments - and included a wide range of actors such as foreign ambassadors, presidents, prime ministers, political parties, donor organizations, staff, students, parents, employers, council members, and state bureaucra- 
cies. The different players brought different agendas to the table as they jostled for advantage, their material interests, and positions of power and privilege. The international players represented by ambassadors of powerful Western countries, country representatives of bilateral agencies, and the Bretton Woods Institutions pushed a seemingly neutral but significantly ideological agenda that argued for efficiency and effectiveness in the universities and higher education systems, along with transparency and accountability. They often held long meetings with oversight ministries and even with the offices of presidents and prime ministers; commissioned consultancies, evaluations, and technical assistance for the reform efforts; and in some cases seconded and paid for managers and administrators of specific components of the reform process. The international dimension, particularly in some countries, was therefore quite evident on the ground through policies, direct negotiations with implementers, the supply of ideas, personnel and equipment for implementation, and the monitoring and evaluation of the implementation process. The BWIs were key actors in working with governments to define the boundaries and substance of deregulation, monitoring them, and rewarding those that moved along rapidly with increased credit and grant facilities.

The reform framework has been central to the current "revitalization" of the universities in Africa; it has led to deregulation and the massive growth of private higher education, thus significantly changing the landscape. It has introduced new management and governance practices and has contributed to increased enrollment. But is it sustainable? Is it built on self-reliance and autonomous growth? Has it transformed institutional cultures of patriarchy, sexism, nepotism, racism, and in some cases, flagrant incompetence and a self-serving orientation? What kind of culture of scholarship is it reproducing? Is it a scholarship able to provide Africans with clear maps for their collective and individual engagement with their respective realities? Or a scholarship driven by a market mission geared mainly toward providing operatives for the subsidiaries of global corporations or men and women who are cultural mimics? The reform process has had many thoughtful critics who understood, with hindsight, the limits of reform. As Ken Prewitt (2004:44) said,

embedding tertiary education in the market has consequences for university reform. There is no way to reform, improve, or otherwise transform universities solely from the inside out. The challenge-not an easy one-is designing educational policies that take into account forces beyond the educational sector.

As Mamdani (2007) pointed out, what was lacking the most in the reform process was a serious and thoughtful engagement with what constitutes the vision, mission, and function of the university in Africa as a whole and for individual African countries. 
Whichever way the above questions are answered, it is obvious that the reform enterprise as it has been constructed so far cannot be a substitute for serious and long-term engagement with the future of higher education in Africa. Neither can the knowledge products it supports and generates contribute to providing sustainable and enduring internal resources capable of helping Africans not only reassert themselves, but also reclaim their humanity through the full realization of their intellectual and other resources. What, then, lies beyond reforms?

\section{Beyond Reforms: Toward a Politics of Higher Education Transformation in Africa}

In contemporary discourses on planned change in African higher education, perhaps the most nebulous notion has been the idea of "transformation." The word has been used as synonymous with reform and systemic change, but it has not received the clarity of definition and specificity that such a political and policy-driven notion deserves. For those who have thought most clearly and deliberately about transformation, particularly some feminist and gender theorists, it refers to an intentional social, political, and intellectual project of planned change aimed at addressing historical disadvantages, inequities, and serious structural dysfunctions. Projects of transformation challenge assumptions, values, and power relations and they offer alternative visions and situations. Transformation implies practical and epistemological ruptures with previous ways of doing things and a reconstruction of structures, relations, cultures, and institutions. In the case of African higher education, transformation entails going beyond reform; it involves a reexamination of inherited institutions and how we think about and live within them, and a reconstructing of these institutions as durable, sustainable structures geared to meet Africa's needs.

More than any other higher education systems on the continent, the South African case presents an overt and deliberate engagement with transformation. As Massen and Cloette (2002:15) tell the story,

Six months after South Africa's watershed first democratic election, Nelson Mandela issued a proclamation appointing a National Commission on Higher Education (NCHE) to "preserve what is valuable and to address what is defective and requires transformation."... This Commission had two central tasks: to rid higher education of the aberrations of apartheid and to modernize it by infusing it with international experiences and best practices.

This, in my view, expresses the true exceptionalism of the current South African experiment. What is most salient about South Africa is not its so-called advanced economic power, or the respected status of some of its universities, but rather the aftermath of apartheid, which had created a racialized 
mix of very unequal institutions: some that you might call underdeveloped and deprived, and others that are as good as any university in the West. The exceptionalism in this case is the success with which South Africa seized the historic opportunity offered by the struggles with apartheid to reinsert "transformation" into the language, practice, and politics of higher education. Of course, this effort must be understood within the context of the politics of the fight against apartheid and the leadership of the African National Congress (ANC), as well as the overall mobilization of the people for change. What the South African experience teaches is that transformation emerged from a history of upheaval, experiences of domination and resistance, struggles, conflicts and crisis, and a recognition of the need to engage with, redress, and transcend such experiences. The South African experience has a great deal to teach us about the nature of national leadership and the tutelage in politics that the protracted anticolonial and antiracist struggles have provided.

I believe that the national trauma that was embodied in South Africa's recent history has its equivalents in the waves of economic and political crises, ecological disasters, wars, conflicts, and epidemics that the rest of Africa has faced. Thus, instead of remaining in a state of denial, the rest of the continent must rise up to the implications of decades of devastation and crises and institute major transformation in all of our key public institutions, the university system included. In social policy terms, we are talking of investments whose goals must echo the boldness of the post-Second World War Marshall Plan for Europe or the rebuilding of Japan.

Universities in Africa are some of the carriers of the knowledge of comparative international experiences, and they can begin the rebuilding effort within themselves. The project of transformation is imperative for rescuing the future of the university in Africa. My intention here is not to romanticize the South African experience. It is very far from perfect, and as many case studies such as that of Greg Anderson (2008) have shown, it is still a work-in-progress and it has many enemies, skeptics, and saboteurs. Recent newspaper stories about the racist acts of some students at the Free State University show how far South Africa still has to go to fight not only institutionalized racism, but also its more insidious expressions hidden in cultural practices, rites of passage, and the routine day-to-day conduct of ordinary lives. But there has been a beginning, and many people and institutions are invested in the process. This process generates debates, anger, euphoria, frustration, and disappointment. But it brings the issues to the surface, and it allows for a level of intentionality and engagement. One does not see much of that in the higher education debates of Nigeria, Kenya, Uganda, and Ghana, where the higher education systems are of comparable size to those of South Africa (if not larger), or in Senegal, Côte d'Ivoire, Ethiopia, Eritrea, and Sudan. If we accept the transformation imperative-and there are many arguments for this direction beyond market competitiveness and international rankings-I would like to suggest here three potential entry 
points that, when pursued simultaneously or carried out in a phased manner, could begin not only to generate the necessary debates, but also to mobilize a fundamental process of change. ${ }^{10}$ These are (1) transformation driven by the goal of attaining gender and other equity; (2) transformation driven by the goal of addressing inequities and deficits in the structures and process of knowledge production that recognizes and values the relevance and co-equality of diverse knowledge systems, including endogenous knowledge and knowledge outside of what Mudimbe (1988) has called the "colonial library"; and (3) transformation that addresses the issues of the sustainability and viability of the university system in Africa.

\section{Levers of Transformation and Their Politics}

\section{Gender Equity}

In spite of the almost century-long existence of the modern university in Africa, the representation, participation, and position of women, and the structures of power, knowledge production, and institutional culture remain a major source of concern. One entry point to a discussion of the larger issues is the question of gender, which has the potential to address equity and access in Africa from a base that both includes and transcends other contested identities. The arguments and statistics attesting to the inequality of women are widely known, and also available is a whole battery of theories, case studies, and mobilization practices for micro-institutional transformation driven by the goal of gender equity. ${ }^{11}$

The politics here operate at different levels, beginning with the more insidious one of formal compliance that counts numbers in enrollment and female representation on faculty but does not engage cultural change, institutional relations of power, governance, or pedagogy that embraces feminist epistemologies and practices. We find official support for gender equity at the international level (gender equity is valorized in global forums), but at national, local, and institutional levels we find significant resistance from patriarchal cultures, political systems, and religions. We also are often confronted by arguments that suggest a tension between excellence and equity and attempt to trivialize empowerment strategies. Excellence and equity are not necessarily opposed. Universities in Africa cannot continue with business as usual in their structures and institutional cultures. Transformation that leads to gender equity has the potential to subject all structures and processes (including technologies) to the fundamental questioning that is required.

\section{The Organization and Process of Knowledge Production}

The world we live in today is a world of rapid and endless changes in society, technology, the state, the economy, and culture. It is a world driven 
further by the imperatives of globalization and its dynamics, and of simultaneous inclusion and exclusion of groups, individuals, and whole regions. Universities are a part of these changes, sites where the changes are documented, studied, and disseminated, and in some cases they are the arenas of struggle for and against the changes, their catalysts and facilitators. From the perspective of knowledge production, some of these changes are affecting the modes of scholarly inquiry, the constitution of disciplines and their boundaries, and the relationships among institutions, knowledge systems, and other parts of society. How are African universities dealing with these challenges, and how do the challenges constitute a basis for the transformation of the universities?

As we have already pointed out, despite the fact that the reform process has revitalized universities and created plural and highly differentiated and diverse players in the system, the extent of significant structural and intellectual innovation among most of these players-new or old-remains limited. Most of the continent's institutions either possess or aspire to possess basic, conventional structures. This goal is further reinforced by the blueprints for accrediting universities used by most of the regulatory institutions. Boldness and imagination in devising academic programs, reviewing and constructing curricula, and introducing innovative pedagogies driven by public good goals are not encouraged by market pressures, limited imagination among regulatory authorities, and the scarcity of resources and capacities. Universities in Africa will need to significantly change their current mode of organizing knowledge production, the nature and content of knowledge, and the kinds of partnerships they seek and pursue in order to be equal players in the global arena while remaining relevant nationally and locally. So far, national systems, staff, and students have not been open to a radical reconfiguration of how universities are structured, operate, or relate to other institutions. Also, many universities and knowledge-producing systems are happy with the way things are. They are not troubled that African universities operate at the fourth and fifth tiers of global knowledge production. They have no objections to African universities' remaining as the waiting rooms of one of the world's greatest social laboratories. But this is the problem of Africa as a whole, not just of the universities. The necessity and relevance of research universities with missions that balance local relevance with global engagement is a debate that must begin on the continent, and change must be implemented there as well. If a consensus is reached, or indeed if a way forward is envisioned collectively, then Africans must also decide who is going to pay for such universities and how. Indeed, one of the biggest challenges today is that the peoples of different African countries must decide that they really want a university and they must be ready and willing to sustain it and own it. The transformations that occur at this level will then have implications for the future of the university in Africa. 


\section{The Sustainability of the University}

Can the public university survive as it is currently constituted in terms of form, governance, relationships, and resources? Although I am not a futurologist, my cautious response is "no." As the sector grows in response to enrollment pressures and other demands, there is a need to seriously transform funding sources and mechanisms. ${ }^{12}$ Some countries are devising innovative public finance mechanisms such as using a proportion of their direct and indirect tax revenues on minerals and the consumption of luxury and other goods to subsidize higher education. ${ }^{13}$ We will have to see more of these and new forms of mergers and acquisitions, the return to regional universities with national campuses, the creation of innovative relationships with industry, faith-based organizations, not-for-profits, and with individual researchers and academics. This will be the core of a reregulation that will provide institutional flexibility in operations, governance, and accountability while ensuring that quality is advanced and the rights of students and staff are protected.

Differentiation will have to continue as a process in higher education. Not all African countries have the capacity to sustain even one research university or a comprehensive university. Some need only the equivalent of small liberal arts colleges or even community colleges. But so also will there be the need to rethink equivalences and how credentials can be cumulative and interchangeable across borders. The signs are there in discussions in East Africa around the mobility of staff and students, the portability of qualifications, and the coordinating of courses. When pushed to the possible logical conclusions, the discussions possess tremendous possibilities for organizing research and other universities within increasingly growing and differentiated systems. It means that we have to think differently about regional integration. It means that we have to reconsider the mechanics of sourcing and providing finances and how we recruit, deploy, maintain, and advance staff and researchers. We now talk of split-site doctoral training. The era of split-site academic staff and researchers who work across different borders in one academic year may not be too far off and may not be restricted to the super-professors with multiple chairs in Africa and abroad. What seems to be unique, privileged arrangements might need to become routine modes of organizing universities and higher education systems if they are to be transformed and sustained. Transformation will not be easy; it will be a long, drawn-out process with many crossroads and potholes on the way. It is, however, going to be one of the important routes if the university in Africa is going to survive, thrive, and serve the needs of African nations in particular and humanity at large.

In conclusion, this lecture is a call to think "beyond reforms" when we think about African higher education. It is a call to think about sustain- 
ability and enduring change and to think about what kind of education for what kind of Africa? It is a call to reclaim the will and determination and to match vision with resolve, politics, and policies, along with the relevant mobilization and deployment of resources. It is a call for transformation!

\section{References}

Ade Ajayi, J. F., K. H. Goma Lameck, and G. Ampah Johnson. 1996. The African Experience with Higher Education. London: James Currey.

Adejumobi, Said. 2004. "Economic Globalization, Market Reforms and Social Welfare Services in West Africa." In Globalization and Social Policy in Africa, edited by Tade Akin Aina, Chachage S. L. Chachage, and Elisabeth Annan-Yao, 23-46. Dakar: CODESRIA Books,

Aina, Tade Akin. 1993. "Development Theory and Africa's Lost Decade: Critical Reflections on Africa's Crisis and Current Trends in Development Thinking and Practice." In Changing Paradigms in Development-South, East and West, edited by Margareta Von Troil, 11-26. Uppsala: The Scandinavian Institute of African Studies.

1994. Quality and Relevance: African Universities in the 21st Century. Accra: Association of African Universities.

Anderson, Gregory M. 2002. Building a People's University in South Africa: Race, Compensatory Education, and the Limits of Democratic Reform. New York: Peter Lang.

Anyang' Nyong' O, Peter. 1989. "State and Society in Kenya: The Disintegration of the Nationalist Coalitions and the Rise of Presidential Authoritarianism, 19631978." African Affairs 88 (35): 229-51.

Assie-Lumumba, N'Dri T. 2006. Higher Education in Africa: Crises, Reforms and Transformation. Working Papers Series. Dakar: CODESRIA.

Buchert, Lene, ed. 1998. Education Reform in the South in the 1990's. Working Papers Series. Paris: UNESCO Publishing.

Castells, Manuel. 2009. "Lecture on Higher Education." Centre for Higher Education Transformation, Cape Town, August 7.

Cloete, Nico, and Teboho Moja. "Transformation Tensions in Higher Education: Equity, Efficiency and Development." Social Research 72 (3): 693-722.

Doss, C. Evenson, R. E. Ruther, and N. L. Ruther. 2004 "Introduction and Overview." JHEA 2 (1): 1-14.

Elieshi, Lema, Marjorie Mbilinyi, and Rakesh Rajani, eds. 2004. Nyerere on Education. Dar es Salaam: Haki Elimu.

Ghai, Dharam. 2008. "UN Contributions to Development Thinking and Practice." Development in Practice 18 (6): 767-73.

Ike, Chukwuemeka. 1965. Toads for Supper. London: Collins and Harvill Press.

Kasozi, A. B. K. 2000. University Education in Uganda: Challenges and Opportunities for Reform. Kampala: Fountain Publishers.

2009. Financing Uganda's Public Universities: An Obstacle to Serving the Public Good. Kampala: Fountain Publishers.

Luhanga, M. L. 2009. The Courage for Change: Re-Engineering the University of Dar Es Salaam. Dar Es Salaam: Dar Es Salaam University Press.

Mama, Amina. 2003. "Restore, Reform, but Do Not Transform: The Gender Politics of Higher Education in Africa." JHEA 1(1): 101-25. 
Mamdani, M. 2007. Scholars in the Marketplace: The Dilemmas of Neo-Liberal Reform at Makerere University, 1989-2005. Kampala: Fountain Publishers. 1-10.

2008. "Higher Education, the State and the Market Place." JHEA 6 (1):

Massen, Peter, and Nico Cloette. 2002. "Global Reform Trends in Higher Education." In Transformation in Higher Education: Global Pressures and Local Realities in South Africa, edited by N. Cloete et al., 13-57. Cape Town: Centre for Higher Education Transformation.

Mkandawire, T., and Adebayo Olukoshi, eds. 1995. Between Liberalisation and Oppression: The Politics of Structural Adjustment in Africa. Dakar: CODESRIA.

Mudimbe, V. Y. The Inventing of Africa: Gnosis, Philosophy, and the Order of Knowledge. 1988. Bloomington: Indiana University Press.

Ndebele, S. Njabulo, 2007. Fine Lines from the Box: Further Thoughts about Our Country. Cape Town: Umuzi.

Ogot, Bethwell A. 2009. "Rereading the History and Historiography of the Epistemic Domination and Resistance in Africa." African Studies Review 52 (1): 1-22.

Pereira, Charmaine. 2007. Gender in the Making of the Nigerian University System. Oxford: James Currey.

Prewitt, Kenneth. 2004. "The Higher Education, Society and Government: Changing Dynamics." JHEA/RESA 2 (1): 35-56.

Ramphele, Mamphela. 2008. Laying Ghosts to Rest: Dilemmas of the Transformation of South Africa." Cape Town: Talberg Press.

Republic of South Africa, Department of Education. 2008. "Report of the Ministerial Committee on Transformation and Social Cohesion and the Elimination of Discrimination in Public Higher Education Institutions." November 30.

Sall, Ebrima. 2004. "Alternative Models to Traditional Higher Education: Market Demand, Networks, and Private Sector Challenges." JHEA/RESA 2 (1): 171-212.

Saunders, Stuart. 2000. Vice-Chancellor on a Tightrope: A Personal Account of Climatic Years in South Africa. Cape Town: David Philip Publishers.

Sicherman, Carol. 2005. Becoming an African University, Makerere 1922-2000. Trenton, N. J.: Africa World Press. 11-39.

2008. "Makerere's Myths, Makerere's History: A Retrospect." JHEA 6 (1):

Teferra, Damtew, and Philip G. Altbach, eds. 2003. African Higher Education: An International Reference Book. Bloomington: Indiana University Press.

World Bank. 2009. Accelerating Catch-Up: Tertiary Education for Growth in Sub-Saharan Africa. Washington, D.C.: IBRD.

Zeleza, P. T., and Adebayo Olukoshi, eds. 2004. African Universities in the Twenty-First Century. Volume 1: Liberalisation and Internationalisation. Dakar, CODESRIA. . 2004. African Universities in the Twenty-first Century. Volume 2: Knowledge and Society. Dakar: CODESRIA.

\section{Notes}

1. Matatus is the Kiswahili name given to the often decrepit and colorful autobuses and vehicles that many ordinary people use for mass transit in East Africa, with their equivalents in West and southern Africa. They are often complex public 
spaces with their own art forms, popular cultural symbols, and extensive and often nuanced forms of social and economic relations.

2. In using the term Africa, the complexity of the idea is recognized and it is used here with reference to the geopolitical and legal entity so defined by Africans in their regional institutions such as the African Union. It is a very diverse entity in all aspects-cultures, politics, and the development of higher education. See Ajayi, Goma, and Johnson (1996) and Assie-Lumumba (2006) for insightful analyses of the unity and diversity of the different higher education systems in Africa.

3. Higher education encompasses a broader idea of the tertiary sector in education. This includes universities, which remain the dominant component and perhaps the most important part of the field. See Assie-Lumumba (2006:8-10).

4. These points have been made very clearly for some time by the gender and feminist writers on higher education in Africa. See Pereira (2007) and Mama (2003).

5. See Assie-Lumumba (2006: 93-96). See also Buchert (1998:13-14) on the variety of notions of reform in education.

6. For a review and critique of this approach, see Aina (1993).

7. Most of the references cited in this article make up part of the crisis and reform literature of African higher education even when their goal embraces a wider subject. This is because of the pervasive and deep nature of the crises and the reform experience. Of interest is the emergence of a body of writing by those who were directly engaged in or were studying the universities from the inside in the era of crisis and reform. Senior leaders of African universities such as Luhanga (2009), Kasozi (2003, 2009) and Saunders (2000) have documented their first-hand observations of their experience and research.

8. For a more extensive discussion of these issues, see Adejumobi (2004). See also the various papers in Mkandawire and Olukoshi (1995).

9. The characterization along these three periods is based on what can be said to be the defining issue in the political economies and societies of the countries. These defining issues, although summed up in one single characterization, often embody systemic thrusts or orientations that drive most of the issues and efforts of the period.

10. Some of the more compelling arguments for global competitiveness beyond a market-driven mission have been offered by scholars such Manuel Castells (2009).

11. A tremendous amount of work has been done in gender and feminist studies to address gender equity in higher education in Africa. See Pereira (2007), Mama (2003), and Assie-Lumumba (2006) among others.

12. According to the World Bank (2009:xxvi), there are about 650 tertiary institutions (200 public, 450 private). This underestimates the number, however, as news from the regulatory bodies shows the continuous creation and registration of new institutions.

13. The financing and funding of higher education in Africa is increasingly becoming a significant area of research and engagement. The private U.S. foundation Partnership on Higher Education in Africa has been part of the support of a wide array of comparative studies awaiting publication. See www.foundationpartnership.org. Also see interventions by African university policymakers such as Kasozi (2009). 